\title{
THE NANSEN PASSPORT: \\ A TOOL OF FREEDOM OF MOVEMENT AND OF PROTECTION
}

\author{
Otto Hieronymi \\ Head, International Relations Program and Migration and Refugee Studies, \\ Webster University, Geneva
}

To the memory of my parents who traveled with a ti tre de voyage for thirty years.

The crushing of the Hungarian revolution of October-November 1956 by Soviet troops led to the largest outpouring of refugees since the erection of the iron curtain designed to prevent flight from the communist countries and since the adoption of the 1951 Convention on the Status of Refugees. The people who stayed behind in Hungary were bitterly disappointed because of the lack of help from the leading Western countries and from the United Nations. The refugees, however, benefited from the worldwide sympathy with the cause of Hungarian freedom and independence and were exceptionally well received once they crossed the border as well as in the countries where they were rapidly resettled.

The story of the Hungarian refugees became a success story: for the Hungarian refugees and for the international community as a whole (including IOM and UNHCR), a success story of unprecedented international solidarity with close to 200,000 refugees. Neither before, nor since has there been such an outpouring of solidarity with refugees by governments and the population at large in Europe and virtually throughout the world. ${ }^{1}$

The Hungarian refugees enjoyed both material assistance and the legal protection of their host countries. They found jobs, received scholarships and started a new life under favorable conditions. This was the time in the late 1950s, early 1960s when international tourism and travel began to expand with the growing prosperity of the free world. While most countries still main-tained a general visa requirement, the granting of visas became a mere formality.

It was only normal that the Hungarian refugees wanted to join this movement. With savings from scholarships, first wages or salaries: they wanted to travel. To see the world, Paris, London, Rome, Hamburg, Oslo, New York, Boston or even Sidney and Melbourne, to visit friends and relatives, fellow refugees in other countries. But above all to enjoy the freedom of travel, the freedom of movement: after having been locked

${ }^{1}$ See: Otto Hieromyni: "A World-Wide Success of Solidarity: the Resettlement and Integration of Hungarian Refugees". Paper presented at Migrati on and the Internati onal Community: from Hungary 1956 to the Tasks of Today, a Seminar organised by the Permanent Mission of Hungary in Geneva and Webster University, Geneva on 23 October 2001 on the occasion of the $50^{\text {th }}$ Anniversary of the International Organisation for Migration and the $45^{\text {th }}$ Anniversary of the Hungarian Revolution. 
in for eight years behind the Iron Curtain the possibility to travel was seen as an essential dimension of freedom. To be free to travel justified by itself for many the acceptance of the status of refugee, the separation from family, from home, from country and language and culture. The desire to tra-vel freely also justified the taking of major risks: the risk of serious injury or death (stepping on a mine, being shot by border guards), or the risk of a heavy prison sentence if caught. The standard sentence for "attempts of illegal border-crossing", to use the official terminology, varied from six months to five years in prison, depending on the country and the period².

Thus, it was normal that the great majority of Hungarian refugees, in whichever country they found asylum, took advantage, almost immediately of the possibility of obtaining a refugee passport issued by the authorities of their host countries. For most of them, this ti tre de voyage, this travel document, was the first passport they ever owned.

Also, for many, this travel document became an instrument not only of travel, but also of integration in the host country and in the free world as a whole, as it provided virtually the same freedom and protection, and the same right of return to the issuing country, as the possession of a real national passport ${ }^{3}$.

Of course, very few Hungarians, or refugees from Czechoslovakia in the late 1960s, had heard of the 1951 Convention on the Status of R efugees that provided the international legal basis for the issuance and acceptance of these ti tres de voyage 4 .

E ven fewer Hungarian or Czech refugees knew that the refugee travel document, the ti tre de voyage et d'identi té, had been invented to provide

${ }^{2}$ The Berlin wall to be built in 1961 was only a tiny portion of the Iron Curtain which had been built by the communist countries in the late 1940s dividing Europe for more than 40 years into a free and an unfree part. "Totalitarian States severely restrict travel abroad by their nationals. Passports are difficult to obtain, while illegal bordercrossing and absence abroad beyond the validity of an exit permit can attract heavy penalties. The question is, whether fear of prosecution and punishment under such laws can be equated with a well-founded fear of persecution on grounds of political opinion..." (Goodwin-Gill, p. 53) For people actually living in totalitarian countries, as distinguished from lawyers and officials in free countries, it was obvious that the travel restrictions were an essential part of the political persecution by the regime.

${ }^{3}$ This was particularly important in the European countries where the naturalization process was more lengthy and often less generous and automatic than the granting of asylum. Thus, many refugees used these travel documents for more than five, ten or more years and some of them, whose naturalization requests were not granted, could use them until the end of their lives. Some refugees, who did not gain a new citizenship in the first five to ten years, also used these ti tres de voyage to make visits to their countries of origin (once the political climate allowed it), at the risk of losing their refugee status in the host country, a risk, of course, that the holders of new real passports did not face. (Although, in the passports of American citizens there was a standard warning that the hold may not be able to count on the full diplomatic protection of the American government on the territory of his country of origin.)

${ }^{4}$ Of course, in principle only for the pre-1951 refugees - which in theory did not include the 1956 Hungarian refugees. Fortunately, the practice was more liberal than the theory a phenomenon that is not as unusual even today in the refugee field as many believe. 
protection for the first big wave of refugees produced by communism (and the first wave produced by a totalitarian regime) in history: the Russians who fled or were expelled from Russia in the wake of the October revolution of 1917 and of the ensuing civil war.

Most of them did not know either that the so-called Nansen Passport was to serve other victims of forced migration in the 1920s and the 1930s, and that the Nansen Passport had to be reinvented after the Second World War which had produced another huge wave of refugees - who were fleeing from or because of national socialism or from the spread of communism in the second half of the 1940s.

Article 28 of the 1951 Convention on the Status of Refugees defines the obligation by the Contracting States to issue a travel document to refugees "lawfully staying in their territory... for the purpose of travel outside their territory..." The Schedule and the Annex on the Specimen Travel Document at the end of the Convention define in greater detail the nature of the obligations of the States and of this travel document.

The two principal obligations of the signatory states - and the two principal rights of the refugees holding these travel documents - are:

1. the right to return to the country (of asylum) which issues the travel document ${ }^{5}$, and

2. the possibility to enter other countries which accept these documents as valid passports ${ }^{6}$.

There is no question that together with the obligation of nonrefoulement and the general definition of protection, the travel document

${ }^{5}$ The right to return was and remains essential not only because it assures a safe haven for the holder of the travel document, but also because this is the essential condition for other letting in its holder (as it is also the case for the holders of real national passports). This was recognized by Nansen and remains essential today for all refugees benefiting from the current versions of the Nansen Passport. «Tout déplacement hors des frontières cause déjà des difficultés à l'apatride par suite du défaut de passeport national. Afin de ne pas rendre impossible tout voyage à l'étranger - ce qui ne serait pas dans l'intérêt de l'E tat où l'apatride se trouve - l'E tat de résidence délivre souvent des papiers spéciaux de voyage... La pratique a démontré que de pareils «passeport pour étrangers» peuvent rendre de réels services à leurs bénéficiaires, notamment s'ils leur donnent droit de retour dans le pays de délivrance. Car les Etats sont toujours fort peu enclins d'admettre des étrangers sur leurs territoires, s'ils n'ont pas la certitude que le cas échéant, ils pourront les refouler vers leur pays d'origine.» François, p. 322.

${ }^{6}$ In Western countries, countries of asylum rather than producers of refugees since the Second World War, there has been a rather general acceptance of these titres de voyages since the 1950s. That it takes some time for the administrative practice of countries that used to produce refugees rather than host them (i.e. the former communist countries) to fully recognize the validity of these documents was brought home to the author on the Hungarian-Croatian border in the mid-1990s. During a mi grati on and refugee study trip fully documented and welcomed by the refugee authorities of both countries, the group was held up a Sunday evening up for more than three hours because the travel document issued by the Hungarian authorities held by a young refugee accompanying the group was recognized neither by the Hungarian nor by the Croat border guards. Both sides suggested that the refugee should return to Budapest 
(titre de voyagein French) represents the core of the rights of the refugees and of the international refugee regime.

The inclusion of the detailed specifications of the travel document in the Convention shows the recognition by its the framers five years after the end of the Second World War the importance of the right to travel among the basic human rights that the citizens of the free world should enjoy. If French, English, or Swiss citizens have the right to travel outside their countries, so should the refugees who have been granted refugee status. It should be remembered that one of the first human rights denied to their citizens by the totalitarian regimes, by the National Socialists as much as by the Communists, who were the greatest producers of refugees in the first half of the $20^{\text {th }}$ century, was the right to travel freely - the right to leave and return freely. The Iron Curtain, of which the Berlin Wall was to become the symbol, called "technical border" in the official communist parlance, consisted of barbed wires, mine fields, machine guns and guard dogs, as well as patrols under order to shoot all those who tried to leave. It was the most visible demonstration that under communism a passport was not part of the rights of "Socialist citizens" and attempts of illegal border crossing were crimes to be by a heavy prison sentence if one did not step on a mine or was not shot by one of the guards.

During the Second World War the need to learn from the lessons of the inter-war period was widely recognized in the Western Allied countries, in particular the United States and Britain. It was necessary to learn from the negative lessons, and it was equally important to learn from the (few) positive lessons in successful international cooperation. This recognition was the driving force behind the extensive preparations for international organizations the most important of which were the United Nations and the monetary and financial organizations known under the name of the Bretton Woods institutions.

The best historian of the League of Nations noted that the member countries of the League were reluctant to make financial sacrifices for the refugees and were hoping that the whole refugee issue was a temporary one that would fade away. He also noted that in the refugee area "with the important exception of the Nansen Passport, the (League's) results were small."7

\footnotetext{
"to clear up the situation". It was only the refusal of the rest of the study group, all of whom held real national passports, to continue the journey towards Zagreb without the holder of the Hungarian ti tre de voyage that convinced the border guards of the wisdom of letting the whole group cross the border.

7 "The Council had no choice but to adopt an attitude of the strictest official prudence, since the Members of the League were not prepared to undertake any large financial burden for the sake of the refugees. But refugee settlement cannot be carried out without heavy expenditure: and the league's endeavours were therefore condemned to be a palliative, never a cure. The greatest benefit it bestowed was to provide them with legal protection, above all through the invention of the Nansen Passport - a certificate delivered by national authorities on the recommendation of the High Commissioner or his authorized representatives, which was accepted by more than fifty countries. Refugees and
} 
In view of the tragedy of refugees during the 1930s and especially during the Second World War, it was important to include the refugee issue among the tasks on which Allied planning had to start prior to the end of hostilities. To deal with the impending post-war refugee problem the Intergovernmental Committee on Refugees was created. This Committee, which met in London, could draw on one of the few examples in international cooperation in the 1920s and 1930s with a lasting positive impact on people's lives, and on one of the few positive aspects in the twenty years of humanitarian crises that preceded the outbreak of the Second World War.

Thus, the Committee fully recognized the important role that the Nansen Passport had played during the inter-war period and the need for having a similar instrument for the refugees in the new post-war period:

"At the end of the present war, the Intergovernmental Committee will have to take all appropriate measures within its power to facilitate the permanent settlement of refugees coming within its mandate. There will be some refugees who are unwilling or unable to return to their respective countries of origin or former residence, and who do not enjoy the protection of any Government. Such persons will be found, when the war ends, in neutral European countries, and in Allied countries, which have not been occupied or have recently been liberated. If these persons have to reemigrate to countries of final settlement, it will be necessary to provide them with a document which would serve as a substitute for a national passport, which would be recognised by the countries of transit and the countries of final destination, and on which the authorities of these countries would be prepared to affix the necessary visas. The Intergovernmental Committee has not failed to recognise the importance and urgency of this problem, and on $17^{\text {th }}$ August 1944 during its F ourth Plenary Session, the Committee adopted" a resolution asking for the development by a Commission of Experts to make recommendations for the "adoption and issue of an internationally recognised identity and travel document for stateless persons, or persons not

their families had hitherto been unable to travel, even to places where work was awaiting them or friends were ready to receive them. The question of passports was clearly connected with those of emigration and employment; and once it had been solved, the Refugee Organization, with the help of the International Labour Office, was able to give substantial assistance in these respects.

The Organization was always regarded as temporary, and the Assembly did not fail to remind it each year that it had only a few more years to live. It was an unpopular institution. The refugees themselves were naturally conscious above all of its limitations. Britain, the Dominions, and the overseas countries in general were apprehensive of being asked to contribute to the solution of a problem for which they admitted no responsibility... Its only warm support came from France, the one country that offered welcome and fair treatment to immigrants, and from the Scandinavian countries, for Nansen's sake... (But), with the important exception of the general introduction of the Nansen Passport, the results were small. For the most part his action was carried on by direct negotiation with individual governments. Each year he demanded and the received the approbation of the Assembly, and the funds to keep his staff in being; he never received from the League any greater support than this." Walters, pp. 188-189. 
enjoying the protection of any Govern-ment". These recommendations for a "Preliminary Draft Arrangement" were ready by early 1945. They followed largely the model of the pre-war Nansen Passport and were to become the basis for the Article 28 and the Annex in the 1951 Refugee Convention 8 .

In the last months of the Second World War no one could have imagined the magnitude of the refugee problem that had to be faced in the wake of the war and subsequently as result of the imposition of communist rule on the countries of Eastern and Central Europe. Nor could they have predicted, or were not willing to predict, as the authors of the 1951 Convention were not willing to predict, that the refugee problem was not be a temporary one and that there was a need for a long-term if not a permanent refugee regime. Nevertheless, the insistence on the reintroduction of the refugee identity and travel document showed that the experts did understand the general nature of the refugee problem: it was a fortunate case of remarkable foresight.

The experts' proposal in early 1945 to reintroduce the travel document and its inclusion in the Convention on the Status of Refugees five years later, were also a tribute to the genius and pioneering work of Fridtjof Nansen. In fact the invention and diffusion of the so-called Nansen Passport had been one of the most important aspects of the efforts in the 1920s and 1930s to protect refugees and with the adoption of the 1951 Convention it became the most lasting legacy of the work of the great Norwegian humanitarian. A recent UNHCR publication sums up well this achievement: "Nansen undertook the formidable threefold task of helping refugees to survive, to acquire some sort of legal status and to obtain jobs. A first legal arrangement was adopted in J uly 1922 - and ultimately ratified by fifty-two States, creating the Nansen Passport and defining the status of refugees." ${ }^{\prime 9}$

Initially the Nansen Passport was adopted to help the refugees from Soviet Russia. Gradually, through the 1920s and 1930s it was extended to new groups of refugees and stateless persons, victims of the rampant nationalism, racism and totalitarian persecution of the time ${ }^{10}$.

\footnotetext{
${ }^{8}$ Intergovernmental Commi ttee, p. 9-10.

${ }^{9}$ The Nansen Refugee Award, p. 11.

${ }^{10}$ «Le docteur Nansen, Haut-Commissaire pour l'œuvre des réfugiés russes, rédigea un projet de certificat, qui fut soumis à une nouvelle conférence convoquée à Genève le 3 juillet 1922... L'arrangement de 1922 avait pour objet de présenter une formule de pièces d'identité dont la validité serait reconnue dans tous les pays adhérents... (le) certificat désormais dénommé «Passeport Nansen» - n'impliquerait en aucune façon pour le réfugié le droit dans retour dans l'E tat où il l'avait obtenu, sauf autorisation spéciale de cet Etat... En 1924, on procéda à un arrangement suivant les même lignes... pour les réfugiés arméniens... Une nouvelle conférence se réunit à Genève du 10 au 12 mai 1926, afin d'améliorer les systèmes de certificats d'identité pour les réfugiés... où 24 pays étaient représentés... (d'après la recommandation) de la Conférence de septembre 1927... le titre figurant sur la couverture sera: Ti tre d'i denti téet devoyage.. (Selon) la «Conventi on relati veau Statut international des Réfugi és», signée à Genève le 28 octobre 1933... chacune des Parties Contractantes s'engage à délivrer des certificats Nansen, valable pour un an au moins, aux réfugiés résidant régulièrement sur son territoire.» François, pp. 358-363.
} 
Nansen was concerned both with the material welfare of the refugees and with their human dignity and their legal status. The Nansen Passport was designed to help provide remedies on both accounts. At the same time, he also pioneered a new important function for an international organization. The refugee High Commission could certify the identity of refugees without passing through sovereign state authority. This meant the di rect protection of indi viduals by an internati onal organizati on.11

From the start, with the October revolution and the creation of the Soviet State, the legacy of the Versailles Peace and the collapse of empires in the wake of the World War and throughout the troubled 1920s and 1930s, the issue of refugee status and the issue of statelessness remained closely linked. This was due both to the redrawing of the map of the world where many people ended up without a nationality and as a result of the deliberate policy of denationalization, of depriving people of their nationality and of the protection of their governments. The Russian refugees were the first large group in this category. 12 More were to follow, including the J ews fleeing or expelled from national-socialist Germany. ${ }^{13}$

${ }_{11}^{11}$ "Nansen was desperately concerned to free the refugees from the stultifying immobility of collection points like Constantinople. To achieve this goal the High Commission sought to clear away post-war travel restrictions for refugees... An arrangement of 1928 permitted representatives of the High Commission to exercise important consular functions, certifying identity of refugees and their status as defined by international law. By that time fifty-one governments had agreed to issue and to recognize the Nansen document as it applied to Russian exiles. However limited, the Nansen Passport was a significant achievement: for the first time it permitted determination of the juridical status of stateless persons through a specific international agreement; at a time when governments and bureaucracies increasingly defined the standing of their citizens, it nevertheless allowed an international agency, the High Commission, to act for those whom their countries of origin had rejected." Marrus, p. 94-95.

${ }^{12}$ See Note 8 above.

${ }^{13}$ «La situation des J uifs apatrides en provenance de l'Allemagne est également pitoyable. Beaucoup d'entre eux se sont rendus en France, en Belgique et aux Pays-Bas. Au commencement la Belgique et les Pays-Bas ont appliqué réciproquement la pratique ordinaire de l'expulsion clandestine vers l'autre pays... » François, p. 322.

«Le problème le plus inquiétant dans toute la matière, c'est la tendance nouvelle d'appliquer la dénationalisation et la dénaturalisation à titre de peine.» F rançois p. 371.

«Une mesure autrefois bien connue, qui pouvait avoir les mêmes effets que la dénationalisation, était l'exil. Dans les Etats civilisés cette mesure n'était plus appliquée en e qui concerne les propres sujets... Le Gouvernement soviétique a dénationalisé tous ses émigrés. Par le décret du 15 décembre 1921 et des réglementations ultérieures, ont été déclarées déchues de la nationalité russe, entre autres, les personnes ayant séjourné à l'étranger plus de cinq années sans interruption et qui n'auraient pas reçu des représentations soviétiques à l'étranger des passeports ou des certificats correspondants, ainsi que les personnes ayant quitté la Russie après le 7 novembre sans l'autorisation du Pouvoir soviétique.

L'Italie a édicté en novembre 1926 un arrêté royal par lequel 17 Italiens ont été dénationalisés à cause de leurs actes politiques.

En Allemagne, la loi du 14 juillet 1933 stipule que des sujets du Reich qui ont leur résidence à l'étranger peuvent être déclarés avoir perdu leur nationalité allemande s'ils ont causé du préjudice au prestige allemand par une conduite contraire à leur devoir de loyauté à l'égard du Gouvernement et du peuple allemands. Leur propriété pourra être 
Today, when worldwide travel has reached unprecedented proportions and many borders can be crossed without visa, we still take the existence of passports and the need to carry them, or to carry an identity card, as normal. Few of us realize that this was not always the case. Hundred years ago, passports were considered superfluous, not required for travel between civilized countries, except for diplomats who claimed special treatment. This was the situation in the world on the eve of the First World War, notwithstanding the rise of nationalism throughout Europe. Thus, we find in the $11^{\text {th }}$ edition of the Encyclopaedi a Britannica, published in 1911 and which gives a unique view of the world as it existed at the end of the "long 19th century", the following definition of passport:

"Passport, or safe-conduct in time of war, a document granted by a belligerent power to protect persons and property from the operation of hostilities... In its more familiar sense a passport is a document authorizing a person to pass out of or into a country, or a license or safe-conduct to the person specified therein and authenticating his right to aid and protection. Although most foreign countries may now beentered wi thout passports, the English foreign office recommends travelers to furnish themselves with them, as affording a ready means of identification."14

Michael R. Marrus, the author of one of the most moving histories of the fate of refugees (The Unwanted. European Refugees in the Twenti eth Century) also reminded his readers of what freedom of travel meant in the $19^{\text {th }}$ century: "Throughout the nineteenth century there were no serious administrative impediments to the movement of persons between states. The English author Norman Angell remembered his own youth in the 1890s, when he decided to leave the European continent for America: "I had no

confisquée. La loi a été appliquée par une série de décrets, prononçant la dénationalisation de plusieurs sujets allemands, dont quelques-uns étaient assez connus dans le domaine politique et littéraire.» François, pp. 306-307.

(National-Socialist) "Germany not only forced her own nationals by discrimination and persecution to emigrate, but actually expelled a great number of them, and accordingly a number of other states, especially in E astern Europe were induced to contemplate similar measures in contravention of international law." Balogh, p. 476.

The international response remained quite slow, how ever. "Through the Convention of F ebruary $10^{\text {th }}, 1938$, identity certificates were made available to refugees from Germany, similar to those provided for the Nansen refugees by the Convention of October $28^{\text {th }}$, 1933." Balogh, p. 406.

${ }^{14}$ "Passport", Encyclopaedi a Britannica, Eleventh Edition, 1910-1911, Volume XX, p. 890, emphasis added. Fifty years later the article on "passport" in the current edition of the Britannica included in the definition "the right to leave a country": neither the right to leave nor the right to enter were any longer taken frog granted. "Passport, a formal document or certification issued by a national government identifying a traveler as a citizen with a right to return to that nation. A passport may be required as evidence of authorization to leave a country as well as evidence of the right to return and of the right to aid and protection." "Passport", Encydopédi que Bri tanni ca, 1961, Vol. 17, p. 359.

The recognition of the importance of migration was an essential part of the liberal tradition: «II n'est peut-être aucun phénomène qui ait exercé un rôle aussi important que les migrations sur l'histoire de l'humanité.» Varlez, p. 169. 
passport, no exit permit, no visa, no number on a quota, and none of those things was asked for on my arrival in the United States". ... Passports when he decided to leave the European continent for America: "I had no existed at that time, and a handful of states, including the tsarist and Ottoman empires required them for internal travel. In Russia, the saying went, "No man can exist without a passport". But these documents had largely fallen into disuse internationally, remaining simply as diplomatic instruments to designate persons requiring or requesting special attention. Officials never asked travelers' nationality." 15

As Marrus also points out, after the First World War, a return to peace, to normalcy should have meant the end of wartime restrictions on travel: "As soon as the wartime dust had settled, liberals attempted without success to lift the passport system... These restrictions complicated the lives of refugees in the early 1920s..."16

In the wake of the Great War, the passport was viewed, not only by poets and other dreamers, but also by serious international lawyers, as a medieval instrument that offers no advantages and only drawbacks for civilized states and which they could abandon without any risk:

«Une mesure qui a fortement réduit les rapports internationaux a été l'obligation pour les étrangers de se munir d'un passeport. Cette institution qui avait été abandonnée avant la guerre par la plupart des Etats civilisés, a été rétablie presque partout dès le début de la guerre mondiale, même par les Etats neutres. Ce serait une bénédiction que l'abolition de cet héritage de la diplomatie médiévale, dont les Etats comme les individus ne retirent que des inconvénients et pas un seul avantage» ${ }^{17}$.

Also, according to international law States are supposed to provide protection to both their nationals and to foreigners and these latter should also enjoy most of the individual freedoms (of the nationals), including the freedom to travel freely across national borders: «Les étrangers doivent avoir, selon le droit des gens, le droit à la protection des lois et à l'administration de l'Etat; on doit leur reconnaître aussi la plus grande partie des libertés dites individuelles» ${ }^{18}$.

Sovereignty was also limited with respect to the free entry and in particular with respect to the right to asylum. At the end of the $19^{\text {th }}$ century the Institute of International Law recognized, in connection with the right to asylum, that «l'humanité et la justice obligent les Etats à n'exercer la souveraineté territoriale qu'en respectant, dans la mesure compatible avec leur propre sécurité, le droit et la liberté des étrangers qui veulent pénétrer sur le territoire» ${ }^{19}$. UNHCR and the 1951 Geneva Conventions were originally designed as a temporary institution and a set of temporary rules that would fade

\footnotetext{
${ }^{15}$ Marrus, p. 92.

${ }^{16}$ Marrus p. 93.

${ }^{17}$ Isay, pp. 447-448.

${ }^{18}$ Isay, p. 468.

${ }^{19}$ Coursier, p. 428.
} 
away once the problem of post-war European refugees would be solved. Since then, what was adopted as a response to a temporary need became the foundations of the "international refugee regime" which brings protection and assistance to the countless victims of forced migration throughout the world. Today, it is generally recognized that the international refugee regime, under vastly changing political and material conditions, has made an important contribution to solving the refugee crises in the world ever since the 1950s. Its relevance and flexibility were demonstrated once more during the new crises of the last decade. In the 1990s UNHCR became the UN body most respected by the general public. The basic principles and commitments of the international refugee regime have been solemnly reaffirmed by the member states on the occasion of the $50^{\text {th }}$ anniversary of the Geneva Convention Relating to the Status of Refugees. There is no doubt that the contemporary version of the Nansen Passport remains a central and indispensable component of the international refugee regime through the protection and the freedom of movement that it provides to recognized refugees..$^{20}$ Without the identification and travel document refugee protection would be seriously weakened.

In today's globalized world we face a major paradox.

On the one hand, travel has become truly universal and is organized and facilitated, both for leisure and business on an unprecedented scale.

${ }^{20}$ It is interesting to note that the concept of the Nansen Passport has also benefited the Palestinian refugees who receive assistance from UNWRA. While UNWRA does not provide legal protection as do UNHCR and the 1951 Convention, UNWRA refugees have benefited from Arab travel documents., although a times there have been problems with the renewal and with the right of return to the country issuing these documents.

The following quotes from Takkenberg illustrate these issues:

German Federal Administrative Court (quoted by Takkenberg): "when the person concerned was initially granted the option to return to UNWRA's area of operation, by having been issued a travel document, and then subsequently the governmental authorities of his former host country permanently prevent his return during and after the validity of the travel document. In such a case the person has, regardless of his voluntary departure of UNWRA's area of operations, no control over the continuation of UNWRAprotection or UNWRA-assistance. It is accordingly taken away. ... The (1951) Convention does not imply that refugees are not allowed to leave the area of operations (of UNWRA), for example for a visit or business trip or for employment as migrant workers. Accordingly, the departure from the area with the option to return cannot be held against the refugee in that the protection or assistance could not be considered as having ceased in such a case." Takkenberg, p. 113

German Federal Administrative Court's decision quoted by Takkenberg: "In the case where the foreigner wants to leave the area of operations of UNWRA, he should avail himself of travel documents as required by the host state, and adhere to the duration of their validity. If for whatever reasons he disregards the relevant regulations, the protection or assistance of UNWRA has... not ceased in the sense of the 1951 Convention. It is then also no longer relevant whether the host state later delays, actually complicates, or even explicitly refuses his return." Takkenberg, p. 115.

"Palestinian refugees residing in Egypt... continue to be treated according to the special status provided by the Arab League... when such refugee want to travel they may request an Arab League Travel Document for Palestinian Refugees, but are not provided 
Beside economic and technological factors this has been made possible by the systematic simplification or elimination of bureaucratic obstacles to the passing of borders - for all those who possess regular, national passports or identity cards. The situation for them comes close to or is even better than the one that prevailed in the late $19^{\text {th }}$ century as described above.

At the same time, there is a growing group of disadvantaged who have neither true legal identity nor freedom of movement. These include all the "illegals" in the rich developed countries (many of whom are rejected asylum seekers), as well as the millions of victims of forced migration, displaced by new or protracted and often forgotten conflicts and whose future seems to be permanently blocked.

This article may be concluded with a question: Where is the new Nansen who will invent a new tool that will liberate these millions, as the Nansen Passport has brought freedom and security to millions of recognized refugees since the 1920s, not only for the $r$ own benefit, but for the benefit of the international community as a whole?

with a Convention Travel Document in accordance with Article 28 of the 1951 Convention." Takkenberg, p. 125.

"Palestinians who have moved to the Gulf states, after having originally taken refuge in one of the host countries neighbouring Israel, have largely remained dependent on these countries for the (re)-issue and extension of travel documents." Takkenberg, p. 143.

See also: Otto Hieronymi and Chiara J asson: "The International Refugee Regime and the Need for a New Approach to the Palestinian Refugee Problem" forthcoming in Global Di alogue 


\section{References}

Elemér Balogh: «La Paix Mondiale et le Problème des Réfugiés», Académie deDroit Internati onal, Recueil des Cours, 1949, Librairie du Recueil Sirey, Paris, 1949, Vol. II, pp. 340-507.

Collection of International Instruments and Other Legal Texts Concerning Refugees and Displaced Persons, UNHCR, Geneva, 1995.

Conventi on Relating to the Status of Refugees, Geneva, J uly 1951.

H. Coursier: "The Evolution of International Humanitarian Law", Académie de Droit International, Recueil des Cours, 1960, A.W. Sijthoff, Leyde, 1960, Vol. I, pp. 357-461.

“Passport", Encyclopaedi a Britannica, 1961, Vol. 17, p. 359.

"Passport", Encyclopaedia Britannica, Eleventh Edition, 1910-1911, Volume XX, p. 890.

J.-P. A. François: «Le Problème des Apatrides», Académie de Droit Internati onal, Recueil des Cours, 1935, Librairie du Recueil Sirey, Paris, 1935, Vol. III, pp. 287-375.

Guy S. Goodwin-Gill: The Refugee in International Law, $2^{\text {nd }}$ Edition, Clarendon Press, Oxford, 1996.

J ames C. Hathaway:The Law of RefugeeStatus, Butterworths, Toronto, 1991.

Intergovernmental Committee on Refugees: Preparatory Documents Concerning the Adoption of an Identity and Travel Document for Refugees Coming Within the Mandate of the Intergovernmental Committee, London, 1946.

Ernst Isay: «De la Nationalité», Académi e de Droit Internati onal, Recuei I des Cours, 1924, Librairie Hachette, Paris, 1925, Vol. IV., pp. 429-471.

Michael R. Marrus: The Unwanted. European Refugees in the Twenti eth Century, Oxford University Press, Oxford, 1985.

Lex Takkenberg: The Status of Palestinian Refugees in International Law, Clarendon Press, Oxford, 1998.

UNHCR: The Nansen Refugee Award, Geneva, 2002.

Louis Varlez: «Les Migrations Internationales et Leur Réglementation», Académie de Droit International, Recueil des Cours, 1927, Librairie Hachette, Paris, 1929, Vol. V., pp. 169-347.

F. P. Walter: A History of the League of Nations. Oxford University Press, London, 1967. 